\title{
Mirko Jakovljević
}

Visoka škola za komunikaciju, Beograd, Srbija

Kolašin, Crna Gora

mirko.jakovljevic@viskom.ac.rs

\section{Ecology and Media}

\begin{abstract}
The Sustainable Development Goals (SDGs) are a set of global goals targeting all levels: from a planetary biosphere to a local community. The aim is to end poverty, protect the planet and ensure that all people can enjoy peace and prosperity, now and in the future. The beginning of the Twenty-first century and the last fifteen years of the twentieth century have been the awakening of human consciousness when it comes to ecology and environmental protection. The man of the digital age is slowly becoming aware that a new society is a life-organization characterized by the use of modern technologies and overuse of natural resources and, in some places, already devastated and degraded environments. The modern economy survives on the use of living and inanimate natural resources. Natural resources such as air, water, soil are polluted and some animal species are exterminated in this period. For this reason, it is of great importance to force producing and broadcasting numerous environmental shows on local, regional and global media. Going deeper into the issue, we have to see that the problem should be addressed more and more, reinforcing at the same time the ethics of all people on the planet, which would lead to the adoption of binding norms that would affect people's behavior when it comes to ecology and environmental protection. The media is playing a key role in this issue. A part of the discussion on the concept of conservation, including the main scientific and ethical points of view, is presented in this paper, highlighting the
\end{abstract}


environmental, socio-ecological and ethical aspects behind the comprehensive concept of industry and economy. This paper is about the idea of being the appeal on media regarding the urgent need for socio-environmental ethical personal engagement and collective actions.

Key words: ecology, media, environment, ethics, sustainable development.

\section{Introduction}

Awareness of the interconnectedness of the natural and social environment in the human environment, as well as knowledge about the causes of disturbance and pollution, as well as the impact of their pollution on humans is essential. In building society's relationship to environmental problems, although man's relationship to nature is mediated by the political system, an important place belongs to environmental consciousness (Markovic, 2001: 14). The media is a very important agent that contributes to the activation of individuals and groups in environmental actions, to the proper functioning, in accordance with the acquired environmental knowledge and established environmental values. Media actions can be preventive, in terms of informing the recipients of the pollutants, the situation in the local, regional and global ecological environment, dangers of environmental pollution and damage to natural balance. It is the action of the media that is directly related to socially (un) acceptable environmental behavior. There are hardly any professional papers, or a small number of them, which play the role of the media in the development of awareness for the protection of human environment and the environment.

\section{Social values and environmental awareness}

The environment, the natural environment, and their protection and preservation are integral parts of every Constitution of a country. The impression is that the media has received insufficient attention. The value system of what is desirable, worthy of respect, less valuable, or irrelevant, right or wrong, is built through the process of socialization that every human individual goes through, no matter what time or space of the planet he lives. The value system consists of a set of general beliefs, opinions and attitudes and contains the three most important components: cognitive (value as conception), affective (value as something desirable) and connotative (value as a selection criterion for what is considered important to a community, group , environment ...). (M. Jakovljevic, 2015: 34) The transfer of ecological values to a particular social community could be called ecological orientation (Cifrić, Čulig: 1987: 22-23). This view of the value component, as an integral part 
of environmental awareness, adopted through the mass media, is of particular importance for this work. It explains the specific behaviors of individuals and groups regarding preventative environmental protection against potential sources of environmental threats, in addressing local, regional and global environmental crises, but also in everyday work at the workplace and in the environment. Environmental problems can and must be addressed as cultural or civilization problems. (M.Jakovljevic, 2015: 36)

\section{The Impact of Media on Environmental Behavior}

Human behavior is in accordance with the adopted environmental values, and on the basis of knowledge that has about the environment and its importance for the individual, narrower and wider community, contributes to environmental protection, raising the quality of life. Opposite behavior is also due to an underdeveloped environmental awareness: that it is endangering the environment by irresponsible actions, classifying those people who contribute to larger and smaller scale environmental crises. Media play a special role and has importance in times of ecological crises, major natural disasters, earthquakes, floods, etc. when it is timely, accurate and meaningful broadcasting of messages of invaluable importance. When it comes to the role of the media in the development of environmental awareness, the media has, among other things, the role of a mobilizer, but also a catalyst for certain social processes regarding the environmental situation. The media must, by encouraging citizens to think critically about the ecological environment, actively participate in its evaluation, critically evaluate the degree of threat to the environment and the potential threats to their environment. In particular, the media should allow for "public debate" by confronting opinions on specific and potential environmental problems. (M. Jakovljevic, 2015: 40-41) With such editorial policy and program orientation, the media can influence the political representatives of the community in the field of environmental protection. If media has in its programs specialized broadcast dedicated to the conservation and protection of the environment, the media becomes at the same time a communication channel through which they can pressure potential or actual polluters, or corporations that destroy or exploit natural resources, especially non-renewable energy sources, or destroy wildlife. Change is possible only if one changes his consciousness and his beliefs, and brings the practice into harmony with the "reality" he wants to experience. If we want cleaner cities, we must make sure their cleanliness, in particular, contribute to our behavior, stemming from our conviction (Prodanović, 1987: 396). Or, as Hans Jonas thinks and says, "Act so that the effects of your actions are not devastating to the future possibility of your life" (Jonas, 1990: 193). 


\section{Results of the research}

In order to determine the impact of mass media on the environmental awareness of the population of Montenegro, with the aim of preserving and protecting the environment, research was conducted during which the results were identified, indicating a multi-layered relationship and interactions between the media and recipients of information. The survey was conducted by means of a questionnaire, by random sampling method, on a sample of 100 respondents, 20 from 5 cities in Montenegro. The survey was conducted during January and February 2020, and the respondents answered 8 questions by submitting one of the offered answers, or giving grades from 1 to 5 . The gender structure of the respondents is as follows: $54 \%$ male, $46 \%$ female.

The age stratification of the respondents is as follows: 18 to 27 years: $60 \%, 27$ to 55 years: $32 \%$, over 55 years: $8 \%$.

Educational structure-status of respondents: SE- 55\%, HSE: 5\%, HSS: 40\%. Respondents live in the following cities: Berane, Bijelo Polje, Pljevlja, Niksic, Bar

The cities with specific characteristics of potential sources of environmental threats are covered equally. These pollutants can be thermal power plants, but also high concentrations of cars, high levels of exhaust gases, unbearable noise, and other negativities that accompany urban life. During the research, the general impression was that the current ecological situation is significantly better due to the fact that many factories, pollutants, do not work due to problems, therefore do not pollute, not because a certain environmental strategy has been undertaken.

Table 1:

How do you evaluate the environmental situation in your area?

\begin{tabular}{|l|c|c|}
\hline Answer & $\begin{array}{c}\text { Number of } \\
\text { respondents }\end{array}$ & Percentage \\
\hline Extremely poor & 31 & 31 \\
\hline Poor & 36 & 36 \\
\hline Satisfactory & 16 & 16 \\
\hline Good & 17 & 17 \\
\hline Extremely good & - & - \\
\hline Total & 100 & 100 \\
\hline
\end{tabular}

As shown by the results in Table 1, citizens have a very high degree of criticality about the state of the environment in urban areas,where they live. As many as $67 \%$ of respondents rated the environmental situation in their environment as bad and extremely bad. $33 \%$ consider the condition to be satisfactory and good. 
Table 2: With which media do you most inform yourself about the state of the environment and environmental issues in your environment, country and world?

\begin{tabular}{|l|c|c|}
\hline Answer & $\begin{array}{c}\text { Number of } \\
\text { respondents }\end{array}$ & Percentage \\
\hline TV & 42 & 42 \\
\hline Newspapers & 19 & 19 \\
\hline Radio & 8 & 8 \\
\hline Internet & 31 & 31 \\
\hline Total & 100 & 100 \\
\hline
\end{tabular}

Television in Montenegro still holds high primacy (42\%) (see Table 2). Expectations that the Internet would be by far the most significant mean of informing by which residents of Montenegrin cities were informed about environmental issues had not been materialized. Of these, $31 \%$ said they were mostly informed about the environmental situation in their environment via Internet. Radio as a medium had lost its significance as only $8 \%$ of respondents cited this medium as a source of environmental information. Such a low level of trust in radio shows not only the deterioration of the central radio stations in smaller environments, but also the poor listening of local radio stations, which do not profile themselves as a medium to be trusted by citizens because, more than others, they will adequately report on local problems, could label pollutants, or encourage local actions to improve the environment. There is also a decrease in readership, as can be seen in the fact that the number of citizens who trust the print media is only 19 percent.

Table 3: Your assessment of media coverage on environmental status and problems?

\begin{tabular}{|l|c|c|}
\hline Answer & $\begin{array}{c}\text { Number of } \\
\text { respondents }\end{array}$ & Percentage \\
\hline Extremely poor & 62 & 62 \\
\hline Poor & 16 & 16 \\
\hline Satisfactory & 13 & 13 \\
\hline Good & 9 & 9 \\
\hline Extremely good & - & - \\
\hline Total & 100 & 100 \\
\hline
\end{tabular}

As citizens have shown a high degree of environmental criticality (Table 1) Similarly, the results of Table 3 indicate the high criticality of citizens towards the mass media, where $62 \%$ rated the media reports on environmental status and problems as negative. From this self-image, the media could draw a conclusion in the form of taking action and in the sense of opening an interactive 
communication channel in which citizens would suggest topics for making media contributions, opening channels for citizens to report on their own issues about environmental issues, initiating a public debate, during which environmental officials and environmental experts would be responsible for environmental issues and plans of the environment, not only to journalists, but also to readers, listeners or viewers.

Table 4:

How much does the media help you learn about environmental issues?

\begin{tabular}{|l|c|c|}
\hline Answer & $\begin{array}{c}\text { Number of } \\
\text { respondents }\end{array}$ & Percentage \\
\hline 1 Extremely poor & 43 & 43 \\
\hline 2 Poor & 45 & 45 \\
\hline 3 Satisfactory & 5 & 5 \\
\hline 4 Good & 2 & 2 \\
\hline 5 Extremely good & 5 & 5 \\
\hline Total & 100 & 100 \\
\hline
\end{tabular}

Citizens with a high dose of criticism rate of media content on environmental issues. Table 4 shows that with the lowest score of $43 \%$, they assess how much the media helps them learn about environmental issues. Most gave a satisfactory, good, very good and excellent grade. The results show the importance of the media in educating citizens, as the media, despite their poor assessment of the quality of their content on media issues, continue to be labeled as helping citizens to find out about environmental issues to the highest degree.

Table 5: Which areas of environmental protection are you most interested in?

The citizens of five Montenegrin cities are most concerned with air pollution. This was expected because the city of Pljevlja where the biggest problem was air pollution was covered by the survey (32\%). They are almost equally interested in food protection (2\%) and water protection (25\%).

\begin{tabular}{|l|c|c|}
\hline $\begin{array}{l}\text { Respondents } \\
\text { answers }\end{array}$ & Number & Percentage \\
\hline food safety & 22 & 22 \\
\hline Water safety & 25 & 25 \\
\hline Air pollution & 32 & 32 \\
\hline Forest protection & 8 & 8 \\
\hline Animal protection & 3 & 3 \\
\hline Other areas & 10 & 10 \\
\hline Total & 100 & 100 \\
\hline
\end{tabular}


Table 6: To what extent are environmental issues from your immediate environment represented in the local media?

\begin{tabular}{|l|c|c|}
\hline Answer & $\begin{array}{c}\text { Number of } \\
\text { respondents }\end{array}$ & Percentage \\
\hline Extremely poor & 66 & 66 \\
\hline Poor & 23 & 23 \\
\hline Satisfactory & 6 & 6 \\
\hline Good & 5 & 5 \\
\hline Extremely good & - & - \\
\hline Total & 100 & 100 \\
\hline
\end{tabular}

The poor state of the vast majority of local media is reflected in the results in Table 6, where as many as 66 respondents rated the lowest environmental representation of environmental issues in local media. If there are areas whose media coverage each local media can build trust with the recipients of messages in a short time, then those are environmental problems. The problems of the local media when it comes to environmental issues are twofold: on the one hand, the lack of specialist journalists who would handle such content with the required level of professionalism, and on the other hand, the local media are largely powerless to resist the pressure of local power centers. .

Table 7: Evaluate how much the media has an impact on the formation of citizens' opinions on environmental issues in their area and beyond?

\begin{tabular}{|l|c|c|}
\hline Answer & $\begin{array}{c}\text { Number of } \\
\text { respondents }\end{array}$ & Percentage \\
\hline 1 (not affected at all) & 59 & 59 \\
\hline 2 (not sufficiently affected) & 19 & 19 \\
\hline 3 (influenced) & 17 & 17 \\
\hline 4 (highly influenced) & 5 & 5 \\
\hline 5 (highly influenced) & & 100 \\
\hline Total & 100 & \\
\hline
\end{tabular}

Citizens are not satisfied with media coverage of environmental issues in their environments, and therefore have high expectations of the media when it comes to influencing the formation of citizens' opinions on environmental issues in the immediate and wider environment (Table 7). 59\% think that the media does not affect the citizens' awareness, $19 \%$ think that they are not influential enough, while $5 \%$ of the respondents think that they are very influential, and $17 \%$ think that they have an influence. Too, the results also point to untapped potentials arising from the educational and informational function of the media when it comes to environmental topics. 
Table 8: Evaluate how much the media can influence the Government, competent ministries, agencies, inspections and other state bodies to protect citizens from existing and potential polluters, or to protect the environment?

\begin{tabular}{|l|c|c|}
\hline Answer & $\begin{array}{c}\text { Number of } \\
\text { respondents }\end{array}$ & Percentage \\
\hline 1 (not affected at all) & 10 & 10 \\
\hline 2 (not sufficiently affected) & 18 & 18 \\
\hline 3 (influenced) & 31 & 31 \\
\hline 4 (highly influenced) & 34 & 34 \\
\hline 5 (highly influenced) & 7 & 7 \\
\hline Total & 100 & 100 \\
\hline
\end{tabular}

Citizens believe that the media can influence the Government, ministries, agencies, inspections and other state bodies to protect them from potential pollutants, ie to protect the environment (Table 8). The society is divided on this point. $31 \%$ think the media can influence, $41 \%$ think that they are very influential and have the highest influence on government bodies, $10 \%$ think that they have no influence at all, and $28 \%$ of respondents say that the government and ministries are not sufficiently or completely unaffected by the media. The table shows that the power of the media when it comes to influencing the Government and its ministries is $72 \%$. Citizens believe that the media can influence the Government and ministries, and other state bodies, to address the protection of the environment and the protection of citizens from existing and potential polluters.

\section{Conclusion}

Humanity needs a highly developed awareness of the need for greater alignment between human creative activities in advancing social development and the need to preserve and enhance nature during such development. (Berberovic, Hanjalic, Saric, 1984: 295). Building environmental awareness is closely linked to increasing the impact of the media on the public. For these reasons, a person already living in a kind of "new media order" is advised to acquire a fundamental knowledge of so-called media literacy in order to obtain a more complete picture of the discourse in which the contemporary man is, a clearer definition of his attitude towards the media, but also according to environmental problems and challenges. The media should create the conditions for building a better world than the one in which we face the daily increase of environmental threats. Of all the pollution, the most serious is the pollution of human consciousness. In building and developing environmental awareness, the most important fact is contained in the need to find out the details of the environment. Some of the tendencies in the media sphere have been observed, which distance the media from their basic functions, but serve for new monopolizations, manipulations aimed at imposing the value attitudes of power centers that have a monopoly on capital. The results obtained 
through a survey of 100 respondents from five cities in Montenegro clearly indicate that citizens are highly critical towards the environment, but they are also critical when assessing the quality of media coverage of environmental issues. Citizens place high demands on the media, which, according to this research, does not give adequate treatment to environmental problems. They are especially critical towards the local media, who are not adequately fulfilling their function when timely and meaningful reporting on local environmental issues is needed. The mass media significantly influence not only the formation of environmental awareness, but by shaping awareness, activating the educational function, they provide the recipients with the necessary information and value propositions on environmental issues, on the basis of which they make decisions about specific behavior. The media need to be aware of environmental issues in a timely manner, to report on them substantively, to reflect different opinions and attitudes, but also to initiate and assist the implementation of actions in the field of environmental protection. Environmental protection is a common goal of all participants in social processes.

\section{References:}

Jameton A, Pierce J. (2001): Environment and health: 8. Sustainable health care and emerging ethical responsibilities. CMAJ. 2001 Feb 6; 164 (3): 365-9.

Julesz, M. (2011): Environmental health and social ecology. Orv Hetil. 2011 Dec 4; 152 (49): 1962-4.

Morton S, Pencheon D, Bickler G. (2019): The sustainable development goals provide an important framework for addressing dangerous climate change and achieving wider public health benefits. Public Health. 2019 Sep; 174: 65-68. Epub 2019 July 15

Morton, S., Pencheon, D., Squires, N. (2017): Sustainable Development Goals (SDGs), and their implementation: A national global framework for health, development and equity needs a systems approach at every level . Br Med Bull. 2017 Dec 1; 124 (1): 81-90. doi: 10.1093 / bmb / ldxo31.

Markovic, D. Ž. (2001). Social ecology. Nis: Enlightenment; Belgrade: Contemporary Administration;

Cifrić, I., Čulig, B. (1987). Youth environmental awareness. Zagreb: Center for Social Affairs;

Henslin. JM (2005). Sociology. Boston / New / York / San Francisco

Prodanović, Tomislav (1987). The role of science and education in the development of environmental awareness. University of today, Belgrade.

Jonas, H. (1990). The principle of responsibility - an attempt at an ethics for technological civilization. Sarajevo: Veselin Masleša; 
Berberovic, LJ., LJ. Hanjalić, K., Šarić, T. (1984). University and environmental challenge. Proceedings of the 32nd Session of the International Seminar "University Today", Dubrovnik;

Jakovljevic, M. (2015) The Impact of Mass Media on the Development of Ecological Awareness, Bijelo Polje, Pegaz

Palevic, M., Spalevic, V., Skataric, G., Milisavljevic, B., Spalevic, Z., Rapajic B., Jovanovic, L. J.. (2019): Environmental responsibility of Member States of the European Union and Candidate countries. Journal of Environmental Protection and Ecology, 19 (2): 886-895.

Sestras, P., Bondrea, M., Cetean, H., Salagean, T., Bilasco, S., Nas, S., Spalevic, V., Fountas, S., Cimpeanu, S (2018): Ameliorative, Ecological and Landscape Roles of Făget Forest, ClujNapoca, Romania, and Possibilities of Avoiding Risks Based on the GIS Landslide Susceptibility Map. Notulae Botanicae Horti Cluj-Napoca Agrobotanics: 46 (1): 292-300.

Spalevic, V., Lakicevic, M., Radanovic, D., Billi, P., Barovic, G., Vujacic, D., Sestras, P., Khaledi Darvishan, A. (2017): Ecological-Economic (Eco- Eco) modeling in the river basins of the Mountainous regions: Impact of land cover changes on sediment yield in the Velicka River in Montenegro. Notulae Botanicae Horti Cluj-Napoca Agrobotanics: 45 (2): 602-610. Impact of land cover changes on sediment yield in Velicka Rijeka in Montenegro. 


\section{Ekologija i mediji}

\section{Sažetak}

Početak novog tisućljeća i prethodnih petnaest godina karakterizira, svjedoci smo, buđenje ljudske svijesti kada je riječ o ekologiji i zaštiti okoliša. Čovjek koji preživi u doba digitalnih tehnologija polako razvija svijest da je potrebna nova organizacija društva i života u vremenu opterećenom modernim tehnologijama i pretjeranom upotrebom prirodnih resursa, a na nekim mjestima i već devastiranom i degradiranom okolišu. Suvremeno gospodarstvo preživljava od upotrebe živih i neživih prirodnih resursa. Došlo je do zagađenja zraka, vode, zemlje, izumiranja životinjskih vrsta. Iz tog su se razloga čisto ekološki problemi rješavali proizvodnjom i emitiranjem niza ekoloških programa na lokalnim, regionalnim i globalnim medijima. Ulazeći dublje u problem, moramo vidjeti da se problem mora riješiti prevladavanjem ekonomskih imperativa, istodobno, jačanjem etike svih ljudi na planetu, što bi dovelo do usvajanja obvezujućih normi koje bi utjecale na ljudsko ponašanje kada se radi o ekologiji i zaštiti okoliša. Mediji u tome moraju igrati ključnu ulogu.

Ključne riječi: ekologija, mediji, okoliš, etika, održivi razvoj.

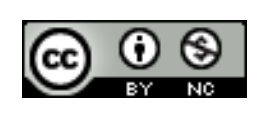

This journal is open access and this work is licensed under a Creative Commons Attribution-NonCommercial 4.0 International License. 